\title{
Effects of dietary fats (fish, olive and high-oleic-acid sunflower oils) on lipid composition and antioxidant enzymes in rat liver
}

\author{
Valentina Ruiz-Gutiérrez ${ }^{1}$, Alonso Pérez-Espinosa ${ }^{1}$, Carmen María Vázquez ${ }^{2}$ and \\ Consuelo Santa-María ${ }^{3 *}$ \\ ${ }^{1}$ Instituto de la Grasa y sus Derivados, CSIC, apdo 1078, Sevilla, Spain \\ ${ }^{2}$ Departamento Fisiología y Biología Animal, Facultad de Farmacia, c/ Professor García González s/n, 41012, Sevilla, Spain \\ ${ }^{3}$ Departamento de Bioquímica, Bromatología y Toxicología, Facultad de Farmacia, c/ Professor García González s/n, 41012, \\ Sevilla, Spain
}

(Received 22 September 1998 - Revised 12 April 1999 - Accepted 28 April 1999)

\begin{abstract}
The effects of two oleic-acid-rich diets (containing olive oil, OO, and high-oleic-acid sunflower oil, HOSO) on plasma and liver lipid composition detoxification enzyme activities, were compared with those of a fish-oil (FO) diet and a control diet. Compared with the control diet, plasma and hepatic total triacylglycerol concentrations were increased in the animals fed on the HOSO and OO diets and decreased in those fed on the FO diet. The animals fed on FO showed the highest level of cholesterol in the liver and had lower plasma cholesterol concentrations when compared with those fed on the two oleic-acid-rich diets. In comparison with the animals fed on the diets enriched in oleic acid, the FO group showed higher hepatic levels of polyunsaturated fatty acids of the $n-3$ series and lower levels of fatty acids of the $n-6$ series. Livers of FO-fed rats, compared with those of OO- and HOSO-fed rats showed: (1) significantly higher activities of catalase $(E C$ 1.11.1.6) glutathione peroxidase $(E C$ 1.11.1.9) and $\mathrm{Cu} / \mathrm{Zn}$ superoxide dismutase (EC 1.15.1.1); (2) no differences in the NADPH-cytochrome $c$ reductase (EC 1.6.99.3) activity. The HOSO diet had a similar effect on liver antioxidant enzyme activities as the OO diet. In conclusion, it appears that changes in the liver fatty acid composition due mainly to $n$ - 3 lipids may enhance the efficiency of the antioxidant defence system. The two monounsaturated fatty acids oils studied (OO and HOSO), with the same high content of oleic acid but different contents of natural antioxidants, had similar effects on the antioxidant enzyme activities measured.
\end{abstract}

Fatty acids: Antioxidant enzymes: Oleic acid

Many clinical studies have indicated that diets rich in fish are associated with cardiovascular health (Kromhout et al. 1985; Herold \& Kinsella, 1986). The responsible component of fish appears to be the high content of polyunsaturated fatty acids (PUFA) of the $n-3$ series (Bang et al. 1986). However, there is growing concern that habitual intake of large quantities of PUFA may induce carcinogenesis, probably because they are very susceptible to peroxidation and production of free radicals (Kok et al. 1994; Fang et al. 1996). The production of free radicals has been associated with ageing (Harman, 1992); however, some studies indicate that fish oil (FO) seems to extend the life span in animal models of autoimmune disease (Jeng \& Fernandes, 1989).

The role of the antioxidant defence system, which includes $\mathrm{Cu} / \mathrm{Zn}$ superoxide dismutase (EC 1.15.1.1; $\mathrm{Cu}$ / Zn SOD), catalase (EC 1.11.1.6; CAT), and glutathione peroxidase ( $E C$ 1.11.1.9; GSH-Px), in protection against oxidative insults is well characterized in the liver, and it has been suggested that this antioxidant defence system may be influenced by nutrition (Huang et al. 1994).

Besides FO, olive oil (OO), an oil rich in monounsaturated fatty acids (MUFA), is also related to cardiovascular health. OO is beneficial in lowering LDL-cholesterol but not HDL-cholesterol, and decreasing the susceptibility of the LDL to oxidation, which in turn reduces the atherogenicity of the LDL and the development of CHD (Mattson \& Grundy, 1985). It has been reported that oleic acid is not necessarily the only component responsible for this effect and that other antioxidant compounds contained in the nonglyceride fraction of $\mathrm{OO}$, such as sterols and polyphenols, may contribute to these beneficial results (Papadopoulos \& Boskou, 1991). Although the traditional source of dietary MUFA is OO, other sources are now becoming available such as the new high-oleic-acid variety of sunflower oil

\footnotetext{
Abbreviations: CAT, catalase; FO, fish oil; GSH-Px, glutathione peroxidase; HOSO, high-oleic-acid sunflower oil; MUFA, monounsaturated fatty acids; OO, olive oil; PUFA, polyunsaturated fatty acids; SOD, superoxide dismutase.

* Corresponding author: Dr Consuelo Santa-María, fax +34 95423 3765, email csm@cica.es
} 
(HOSO), which has a similar fatty acid composition but different antioxidant content (Perez-Jiménez et al. 1995). Compared with FO, the rate of peroxidation and production of free radicals in the MUFA oils is lower.

The aim of the present study was to compare the effects of dietary FO, OO and the HOSO on plasma and hepatic lipid composition and on some hepatic antioxidant enzyme activities. The results show that the behaviour of CAT, $\mathrm{Cu} / \mathrm{Zn}$ SOD and GSH-Px seems to be related to the $n-3$ content of lipid in the liver. The FO diet provided the greatest antioxidant capability whilst the $\mathrm{OO}$ and HOSO diets behaved similarly with regard to the antioxidant enzyme activities.

\section{Methods}

\section{Animals and diets}

Male Wistar rats (Letica, Barcelona, Spain), weighing about $80 \mathrm{~g}$ at the beginning of the experiments, were used. The animals were housed in a well-ventilated room maintained at $22 \pm 2^{\circ}$ on a $12 \mathrm{~h}$ light-dark cycle. The rats were randomly divided into four groups of ten animals. Each group was fed on one of the following diets for 12 weeks: a semipurified diet (basal diet) containing $20 \mathrm{~g}$ unspecified lipid/kg, purchased from Panlab SRL (Barcelona, Spain) (control group) or the basal diet supplemented with $100 \mathrm{~g} / \mathrm{kg}$ $\mathrm{OO}$ (OO group) or HOSO (HOSO group) or FO (FO group). The composition of the experimental diets is shown in Table 1. To minimize oxidation, all diets were prepared once weekly and stored at $4^{\circ}$ under an atmosphere of $\mathrm{N}_{2}$ until needed. Changes in composition during storage were not detected.

The fatty acid compositions of the oils were determined and are shown in Table 2. The non-fatty-acid components of the oils are presented in Table 3.

Table 1. Composition of experimental diets $(\mathrm{g} / \mathrm{kg})$

\begin{tabular}{lcccc}
\hline Ingredients & Control & OO & HOSO & FO \\
\hline Casein & 209 & 203 & 203 & 203 \\
Sucrose & 450 & 374 & 374 & 374 \\
Maize starch & 202 & 180 & 180 & 180 \\
Lipids & 20 & 20 & 20 & 20 \\
OO & - & 100 & - & - \\
HOSO & - & - & 100 & - \\
FO & - & - & - & 100 \\
Cellulose powder & 52 & 56 & 56 & 56 \\
Mineral mix & 57 & 57 & 57 & 57 \\
Vitamin mix & 10 & 10 & 10 & 10 \\
Total energy (MJ) & $15 \cdot 2$ & 17.1 & 17.1 & 17.1 \\
$\quad$ Protein (\% energy) & 23.1 & 19.7 & 19.7 & 19.7 \\
$\quad$ Lipid (\% energy) & 4.9 & 26.3 & 26.3 & 26.3 \\
Carbohydrate (\% energy) & 71.9 & 53.9 & 53.9 & 53.9 \\
\hline
\end{tabular}

OO, olive oil; HOSO, high-oleic-acid sunflower oil; FO, fish oil.

* Mineral mix contained (mg/g): $\mathrm{NaCl} 139 \cdot 3, \mathrm{~K}_{2} \mathrm{HPO}_{4}$ 389.1, $\mathrm{CaCO}_{3} 381.4$, $\mathrm{MgSO}_{4} \cdot 7 \mathrm{H}_{2} \mathrm{O} 57 \cdot 3, \mathrm{FeSO}_{4} \cdot 7 \mathrm{H}_{2} \mathrm{O} 27 \cdot 0, \mathrm{MnSO}_{4} \cdot \mathrm{H}_{2} \mathrm{O} 4 \cdot 0, \mathrm{ZnSO}_{4} \cdot 7 \mathrm{H}_{2} \mathrm{O} 1 \cdot 25$, $\mathrm{KI} 0.8, \mathrm{CuSO}_{4} .5 \mathrm{H}_{2} \mathrm{O} 0.5, \mathrm{CoCl}_{2} \cdot 6 \mathrm{H}_{2} \mathrm{O} 0.02$.

† Vitamin mix provided (/kg diet): retinol $5.9 \mathrm{mg}$, calciferols $0.15 \mathrm{mg}$, thiamin $20 \mathrm{mg}$, riboflavin $15 \mathrm{mg}$, niacin $70 \mathrm{mg}$, pyridoxine $10 \mathrm{mg}$, inositol $150 \mathrm{mg}$, cobalamin $50 \mu \mathrm{g}$, tocopherols $170 \mathrm{mg}$, vitamin $\mathrm{K} 40 \mathrm{mg}$, choline $1.36 \mathrm{~g}$, pteroylmonoglutamic acid $5 \mathrm{mg}, p$-aminobenzoic acid $50 \mathrm{mg}$, biotin $0.3 \mathrm{mg}$.
Table 2. Fatty acid composition of dietary fats $(\mathrm{g} / 100 \mathrm{~g}$ total fatty acids)

\begin{tabular}{lcccr}
\hline Fatty acids & Control & OO & HOSO & FO \\
\hline $14: 0$ & - & - & - & $3 \cdot 8$ \\
$16: 0$ & $13 \cdot 2$ & $11 \cdot 8$ & $4 \cdot 3$ & $13 \cdot 9$ \\
$16: 1 n-7$ & $1 \cdot 2$ & $0 \cdot 9$ & $0 \cdot 1$ & $15 \cdot 1$ \\
$17: 0$ & - & $0 \cdot 4$ & $0 \cdot 1$ & - \\
$18: 0$ & $3 \cdot 1$ & $2 \cdot 8$ & $4 \cdot 7$ & $0 \cdot 9$ \\
$18: 1 n-9$ & $36 \cdot 8$ & $79 \cdot 2$ & $80 \cdot 2$ & $26 \cdot 2$ \\
$18: 2 n-6$ & $41 \cdot 7$ & $3 \cdot 5$ & $9 \cdot 4$ & $5 \cdot 1$ \\
$18: 3 n-3$ & $4 \cdot 1$ & $0 \cdot 6$ & $0 \cdot 1$ & $0 \cdot 2$ \\
$18: 4 n-3$ & - & - & - & $2 \cdot 5$ \\
$20: 0$ & - & $0 \cdot 3$ & $0 \cdot 4$ & - \\
$20: 1 n-9$ & - & $0 \cdot 2$ & $0 \cdot 2$ & $2 \cdot 4$ \\
$20: 2 n-6$ & - & - & - & $1 \cdot 4$ \\
$20: 3 n-6$ & - & - & - & $0 \cdot 4$ \\
$20: 4 n-6$ & - & - & - & $0 \cdot 6$ \\
$20: 5 n-3$ & - & - & - & $13 \cdot 8$ \\
$22: 4 n-6$ & - & - & - & $0 \cdot 3$ \\
$22: 6 n-3$ & - & - & - & $12 \cdot 7$ \\
$24: 0$ & - & $0 \cdot 4$ & $0 \cdot 4$ & - \\
\hline 00,0 & & & &
\end{tabular}

OO, olive oil; HOSO, high-oleic-acid sunflower oil; FO, fish oil.

\section{Blood sampling and tissue preparations}

At completion of the study the animals were killed by cervical dislocation. To minimize diurnal variations the rats were routinely killed between 09.00 and 10.00 hours. Blood samples were removed from the heart and collected into tubes containing EDTA (1 g/l). Plasma was separated by low-speed centrifugation at $1500 \mathrm{~g}$ at $4^{\circ}$ for $30 \mathrm{~min}$ and was immediately analysed. Cholesterol, phospholipids and triacylglycerols were determined using an autoanalyser and conventional enzymic methods (Nelson, 1972; Bucolo \& David, 1973; Allain et al. 1974).

The livers were immediately rinsed in ice-cold $0 \cdot 145 \mathrm{M}$ $\mathrm{NaCl}$, trimmed and quickly weighed. A $2 \mathrm{~g}$ portion of liver was used for lipid extraction and the rest was used to determine enzyme activities. All subsequent processing procedures were carried out at $0-4^{\circ}$. Homogenates $(100 \mathrm{~g} / \mathrm{l})$

Table 3. Composition of the non-fatty-acid components of the experimental oils

\begin{tabular}{|c|c|c|c|}
\hline & $\mathrm{OO}$ & HOSO & $\mathrm{FO}$ \\
\hline Total unsaponifiable fraction $(\mathrm{g} / \mathrm{kg})$ & 15 & 10 & 11 \\
\hline Total sterols (mg/kg) & 1696 & 1754 & 1500 \\
\hline Cholesterol (\%) & 0.15 & 0.01 & 100 \\
\hline Brasicasterol (\%) & - & 0.32 & - \\
\hline Campesterol (\%) & 3.80 & $10 \cdot 25$ & - \\
\hline Stigmasterol (\%) & 0.81 & 11.59 & - \\
\hline$\beta$-Sitosterol (\%) & 93.99 & $59 \cdot 35$ & _ \\
\hline$\Delta-5$-Avenasterol (\%) & - & $2 \cdot 88$ & - \\
\hline$\Delta$-7-Stigmasterol (\%) & 0.22 & 11.84 & - \\
\hline$\Delta-7-$ Avenasterol (\%) & 0.15 & 3.27 & - \\
\hline Squalene $(\mathrm{mg} / \mathrm{kg})$ & 3000 & 90 & 7400 \\
\hline Tocopherols (mg/kg) & 47 & 10 & 300 \\
\hline$\alpha$-Tocopherols & 34 & 10 & 300 \\
\hline$\gamma$-Tocopherols & 13 & - & - \\
\hline Fraction of polyphenols (mg/kg) & 470 & - & - \\
\hline Total polyphenols $(\mathrm{mg} / \mathrm{kg}$ ) & 430 & - & - \\
\hline Ortodiphenol (mg/kg) & 40 & - & _- \\
\hline
\end{tabular}

OO, olive oil; HOSO, high-oleic-acid sunflower oil; FO, fish oil. 
were prepared in $0.25 \mathrm{M}$-sucrose, $1 \mathrm{mM}$-EDTA, $1 \mathrm{mM}$-DLdithiothreitol and $15 \mathrm{mM}$-Tris $\mathrm{HCl}(\mathrm{pH} \mathrm{7.4)}$ ), using an allglass Potter Elvehjem homogenizer (Selecta, Barcelona, Spain). Each homogenate was centrifuged for $20 \mathrm{~min}$ at $800 \mathrm{~g}$. The resulting supernatant fraction was used to determine enzyme activities.

\section{Extraction and separation of lipids}

Quantitative extraction of total lipids from $2 \mathrm{~g}$ liver was carried out following the method of Folch et al. (1957) in the presence of butylated hydroxytoluene as antioxidant. Tissue dissociation was achieved by homogenization in icecold chloroform-methanol $(2: 1, \mathrm{v} / \mathrm{v})$ containing $0 \cdot 1 \mathrm{~g}$ BHT/1 using an Ultra-Turrax model Type TP-18-1 (Ultra-Turrax, Vineland, NJ, USA).

The lipid extract was quantified gravimetrically and kept in stoppered tubes under $\mathrm{N}_{2}$ at $-30^{\circ}$ until the assays. Lipid composition was determined by means of the Iatroscan TLC technique with flame ionization detection (De Schrijver \& Vermeulen, 1991). The Iatroscan MK-5 (Iatron Laboratories Inc., Tokyo, Japan) was used in combination with Chromarods $\mathrm{S}$, which have a precoated active silica thin layer. Samples of total lipids $(3 \mu \mathrm{l})$ were spotted onto each rod, using a $10 \mu \mathrm{l}$ Hamilton syringe. To separate total lipids, rods were developed in hexane-diethyl ether-formic acid ( $90: 10: 2$, by vol.). Rods were scanned under the following conditions: $\mathrm{H}_{2}$ flow, $150 \mathrm{ml} / \mathrm{min}$; air flow, $1750 \mathrm{ml} / \mathrm{min}$; scanning speed, $47 \mathrm{~mm} / \mathrm{s}$; chart speed, $42 \mathrm{~mm} / \mathrm{min}$. An Iatrocorder TC-11 integrator was used for recording and area integration.

\section{Fatty acid analysis}

Fatty acids ( $\mathrm{g} / 100 \mathrm{~g}$ total fatty acids) were determined by GC, as previously described (Molina et al. 1989). The samples were saponified by heating for $25 \mathrm{~min}$ with $5 \mathrm{ml}$ $0.2 \mathrm{M}$-sodium methylate and heated again at $80^{\circ}$ for $25 \mathrm{~min}$ with $\mathrm{H}_{2} \mathrm{SO}_{4}$ in anhydrous methanol $(60 \mathrm{~g} / \mathrm{l})$. The fatty acid methyl esters thus formed were eluted with hexane and analysed in a Hewlett Packard 5890 series II GC equipped with flame ionization detector and using an Omegawak 320 fused silica capillary column $(30 \mathrm{~m} \times$ $0.32 \mathrm{~mm}$ i.d., $0.25 \mathrm{~mm}$ film). The initial column temperature was $200^{\circ}$, which was held for $10 \mathrm{~min}$, then programmed from $200-230^{\circ}$ at $2^{\circ} \% \mathrm{~min}$.

\section{Non-fatty-acid components}

For the extraction of the unsaponifiable matter, $20 \mathrm{~g}$ oil was saponified for $30 \mathrm{~min}$ with $75 \mathrm{ml}$ of ethanolic $\mathrm{KOH}(100 \mathrm{~g} / \mathrm{l})$. The solution was transferred to a $5000 \mathrm{ml}$ decanting funnel, $100 \mathrm{ml}$ distilled water was added, and the mixture was extracted with $100 \mathrm{ml}$ portions of hexane. The hexane solution was evaporated to dryness in a rotary evaporator at $30^{\circ}$ under reduced pressure. The sterol fraction was analysed by capillary GLC (Garcia Regueiro et al. 1994). Tocopherols were analysed by HPLC (Kramer et al. 1997). For the assay of squalene, the hydrocarbon fraction was separated from the oil by column chromatography on silica gel and analysed by capillary GLC (Sulpice \& Ferezou,
1984). The composition of the polyphenols fraction was determined by capillary GLC (Arce et al. 1998).

\section{Enzyme activities}

CAT activity was assayed according to the method of Beers $\&$ Sizer (1952). The final concentrations in the cuvettes were $0.5 \mathrm{M}-\mathrm{KH}_{2} \mathrm{PO}_{4}(\mathrm{pH} 7), 100 \mathrm{~mm} \mathrm{H}_{2} \mathrm{O}_{2}$ and $0.05-0.1 \mathrm{mg}$ tissue sample. The decrease in the absorbance at $240 \mathrm{~nm}$ after the addition of the substrate was followed spectrophotometrically.

GSH-Px activity was assayed with a coupled enzyme system in which GSSG reduction was coupled to NADPH oxidation by glutathione reductase (EC 1.6.4.1; Lawrence \& Burk, 1976). The assay mixture contained $0 \cdot 1 \mathrm{M}-\mathrm{KH}_{2} \mathrm{PO}_{4}$

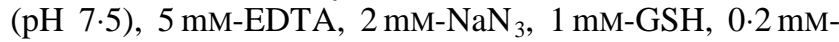
$\mathrm{NADPH}, 1 \mathrm{U}$ glutathione reductase and tissue sample $(0.05-0.2 \mathrm{mg})$. After $5 \mathrm{~min}$ pre-incubation $\left(20-25^{\circ}\right)$, the reaction was initiated by the addition of $0.05 \mathrm{ml} 5 \mathrm{mM}$ $\mathrm{H}_{2} \mathrm{O}_{2}$ (final volume $1.0 \mathrm{ml}$ ). The decrease in the absorbance at $365 \mathrm{~nm}$ was followed spectrophotometrically.

SOD activity was measured using the xanthine oxidase (EC 1.2.3.2)-cytochrome $c$ method as described by McCord \& Fridovich (1969). The final concentrations in the cuvettes were $50 \mathrm{mM}-\mathrm{KH}_{2} \mathrm{PO}_{4}(\mathrm{pH} 7 \cdot 8), 0 \cdot 1 \mathrm{mM}-\mathrm{EDTA}, 10 \mathrm{mM}$ cytochrome $c, 50 \mathrm{mM}$-xanthine, $50 \mathrm{~mm}$ or $2 \mathrm{mM}$-cyanide, $1 \mathrm{U} \mathrm{CAT}$ and $0.05-1.0 \mathrm{mg}$ tissue sample. The reaction was initiated by the addition of $1 \mathrm{U}$ xanthine oxidase. The inhibition of xanthine oxidase was followed spectrophotometrically at $550 \mathrm{~nm}$. One unit of SOD activity is defined as the amount of enzyme required to inhibit the rate of cytochrome $c$ reduction by $50 \%$.

NADPH-cytochrome $c$ reductase (EC 1.6.99.3) activity was measured as described by Vermilion \& Coon (1978). The $1.0 \mathrm{ml}$ assay mixture contained the following components: $300 \mathrm{mM}$-phosphate buffer (pH 7.7), $0.04 \mathrm{mM}$ cytochrome $c, 0 \cdot 1 \mathrm{mM}$-EDTA, $0 \cdot 2 \mathrm{mM}-\mathrm{NADPH}$ and tissue $(0.05-0.2 \mathrm{mg})$. The reaction was initiated by the addition of the NADPH, and the reduction of cytochrome $c$ was followed spectrophotometrically at $550 \mathrm{~nm}$.

All spectrophotometric measurements were carried out in a Shimadzu 160 A ultraviolet spectrophotometer (Shimadzu Corporation, Kyoto, Japan) with $1.0 \mathrm{ml}$ quartz cuvettes with a light path of $1.0 \mathrm{~cm}$. All enzyme assays were performed at $25^{\circ}$. Specific activities were expressed as $\mathrm{nmol} / \mathrm{min}$ per $\mathrm{mg}$ protein. Protein concentrations were determined by the method of Lowry et al. (1951).

\section{Statistical methods}

All results were subjected to one-way ANOVA, and represent means, with their standard errors, of ten animals per group. Differences in mean values between groups were assessed by the two-tailed Student's $t$ test and were considered statistically different at $P<0 \cdot 05$.

\section{Results}

In the present study, rats in the four experimental groups consumed similar amounts of food (Table 4). Animals fed on diets containing OO or HOSO had similar body weights, 
Table 4. Effect of different dietary fats, fed for 12 weeks, on body weight, food intake, liver weight and liver lipid content in rats* (Mean values with their standard errors for ten rats per group)

\begin{tabular}{|c|c|c|c|c|c|c|c|c|c|}
\hline Diet... & & \multicolumn{2}{|c|}{ Control } & \multicolumn{2}{|c|}{ OO } & \multicolumn{2}{|c|}{$\mathrm{HOSO}$} & \multicolumn{2}{|c|}{$\mathrm{FO}$} \\
\hline Food intake (g/d) & & $20 \cdot 8$ & $1 \cdot 1$ & $21 \cdot 0$ & 0.9 & $22 \cdot 8$ & 1.9 & $19 \cdot 1$ & $1 \cdot 2$ \\
\hline Body wt (g) & $\begin{array}{l}\text { at entry } \\
\text { at } 12 \text { weeks }\end{array}$ & $\begin{array}{c}85 \cdot 1 \\
302 \cdot 4^{\mathrm{a}}\end{array}$ & $\begin{array}{l}2.3 \\
7.8\end{array}$ & $\begin{array}{c}77.6 \\
325.9^{b}\end{array}$ & $\begin{array}{l}3 \cdot 2 \\
6 \cdot 1\end{array}$ & $\begin{array}{c}78 \cdot 3 \\
331 \cdot 1^{b}\end{array}$ & $\begin{array}{r}3 \cdot 1 \\
13 \cdot 2\end{array}$ & $\begin{array}{c}86 \cdot 8 \\
260 \cdot 4^{\mathrm{c}}\end{array}$ & $\begin{array}{l}2 \cdot 4 \\
6 \cdot 6\end{array}$ \\
\hline Liver wt (g) & & $9 \cdot 3^{a}$ & 0.8 & $10 \cdot 4^{a}$ & 0.8 & $9 \cdot 4^{\mathrm{a}}$ & $1 \cdot 2$ & $7 \cdot 5^{b}$ & 0.6 \\
\hline
\end{tabular}

OO, olive oil; HOSO, high-oleic-acid sunflower oil; FO, fish oil.

a,b,c Mean values within a row not sharing a common superscript letter were significantly different: $P<0.05$.

${ }^{*}$ For details of diets and procedures, see Tables 1-3 and pp. 234-235.

but these were higher than those of animals fed on the control or FO diets. Animals fed on the diet containing FO had significantly lower body and liver weights when compared with the other groups; however, the liver:body weight values were similar in all the groups. Liver lipid content was higher in animals fed on the OO and HOSO diets than in those fed on the control or FO diets.

Table 5 shows the effect of dietary fat treatment on plasma lipid content. When compared with the control diet, the HOSO and OO diets led to significant increases and the FO diet led to a significant decrease in plasma triacylglycerol level. Consumption of the FO diet resulted in a decrease in the total cholesterol and phospholipid concentrations in plasma in comparison with the high-oleicacid diets. The HOSO and OO groups did not differ in plasma lipid concentrations, but these were higher than those in the control group.

Total triacylglycerol concentrations in liver are shown in Table 6. The OO-fed group showed the highest values and the FO-fed group the lowest. Total hepatic cholesterol was lowest in the control group and highest in the FO group. OO- and HOSO-fed groups showed intermediate values, and no difference was found between these two high-oleicacid diets. The hepatic phospholipid content was lowest in the animals fed on the control diet. The animals fed on the oil-enriched diets showed similar hepatic phospholipid contents.

Table 7 shows the proportions of fatty acids $(\mathrm{g} / 100 \mathrm{~g}$ total fatty acids) in liver lipids in rats fed on the different diets. The highest proportions of the two major saturated fatty acids, palmitic (16:0) and stearic (18:0) acids, were found in rats fed on the FO and control diets as compared with the high-oleic-acid oil groups. Thus, the levels of total saturated fatty acids in liver were higher in the control and the FO-fed groups in comparison with the animals fed on the diets enriched in oleic acid. The proportions of 18:1n-9 were similar in the OO- and HOSO-fed groups and higher than in the control- or FO-fed animals. The MUFA: saturated fatty acids ratio was consequently increased in animals fed on the two oleic-acid-rich diets compared with the other groups. The FO group had a higher proportion of long-chain PUFA of the $n-3$ series (20:5, 22:5 and 22:6) than the control, OO, or HOSO groups. The FO group also had lower proportions of long-chain PUFA of the $n-6$ series (20:4, 22:4 and 22:5) with respect to the other groups. Therefore the $n-6: n-3$ ratio and the 20:4/18:2 ratio were markedly lower in the FO group.

The animals fed on the FO diet expressed higher CAT activity in the liver (5.06 (SE 0.27) U/mg protein) when compared with the other groups (Fig. 1(a)). The CAT activity was similar in the OO and HOSO groups (approximately $3.70 \mathrm{U} / \mathrm{mg}$ protein). The GSH-Px activity in animals fed on the control diet was 0.63 (SE 0.01) U/mg protein. Feeding the FO diet increased this activity to 0.74 (SE 0.05 ) $\mathrm{U} / \mathrm{mg}$ protein and feeding OO or HOSO decreased the activity to 0.39 (SE 0.02) U/mg protein and 0.47 (SE 0.08) $\mathrm{U} / \mathrm{mg}$ protein respectively (Fig. 1(b)).

The $\mathrm{Cu} / \mathrm{Zn}$ SOD activity was highest in the FO-fed group (3.51 (SE 1.12) U/mg protein) and was significantly higher than in the other groups. The oleic-acid-enriched oils had no effect on $\mathrm{Cu} / \mathrm{Zn}$ SOD activity compared with the control diet (Fig. 2(a)). The activities of NADPH-cytochrome $c$

Table 5. Plasma lipid concentrations in rats fed for 12 weeks on diets containing different fats*

(Mean values with their standard errors for ten rats per group)

\begin{tabular}{|c|c|c|c|c|c|c|c|c|}
\hline \multirow{2}{*}{$\begin{array}{l}\text { Diet ... } \\
\text { Plasma lipid }\end{array}$} & \multicolumn{2}{|c|}{ Control } & \multicolumn{2}{|c|}{$\mathrm{OO}$} & \multicolumn{2}{|c|}{ HOSO } & \multicolumn{2}{|c|}{$\mathrm{FO}$} \\
\hline & Mean & SE & Mean & SE & Mean & SE & Mean & SE \\
\hline $\begin{array}{l}\text { Triacylglycerols }(\mathrm{mmol} / \mathrm{l}) \\
\text { Cholesterol }(\mathrm{mmol} / \mathrm{l}) \\
\text { Phospholipids }(\mathrm{mmol} / \mathrm{l})\end{array}$ & $\begin{array}{l}1.25^{\mathrm{a}} \\
2.02^{\mathrm{a}} \\
1.29^{\mathrm{a}}\end{array}$ & $\begin{array}{l}0.23 \\
0.41 \\
0.12\end{array}$ & $\begin{array}{l}1.72^{\mathrm{b}} \\
2.55^{\mathrm{b}} \\
1.44^{\mathrm{b}}\end{array}$ & $\begin{array}{l}0.12 \\
0.22 \\
0.15\end{array}$ & $\begin{array}{l}1.68^{\mathrm{b}} \\
2.44^{\mathrm{b}} \\
1.46^{\mathrm{b}}\end{array}$ & $\begin{array}{l}0.17 \\
0.23 \\
0.21\end{array}$ & $\begin{array}{l}0 \cdot 89^{\mathrm{c}} \\
2 \cdot 20^{\mathrm{a}} \\
1 \cdot 23^{\mathrm{a}}\end{array}$ & $\begin{array}{l}0.14 \\
0.21 \\
0.15\end{array}$ \\
\hline
\end{tabular}

OO, olive oil; HOSO, high-oleic-acid sunflower oil; FO, fish oil.

${ }^{\mathrm{a}, \mathrm{b}, \mathrm{c}}$ Mean values within a row not sharing a common superscript letter were significantly different: $P<0.05$

${ }^{*}$ For details of diets and procedures, see Tables 1-3 and pp. 234-235. 
Table 6. Liver lipid concentrations in rats fed for 12 weeks on diets containing different fats*

(Mean values with their standard errors for ten rats per group)

\begin{tabular}{|c|c|c|c|c|c|c|c|c|}
\hline \multirow{2}{*}{$\begin{array}{l}\text { Diet ... } \\
\text { Liver lipid }\end{array}$} & \multicolumn{2}{|c|}{ Control } & \multicolumn{2}{|c|}{ OO } & \multicolumn{2}{|c|}{ HOSO } & \multicolumn{2}{|c|}{ FO } \\
\hline & Mean & SE & Mean & SE & Mean & SE & Mean & SE \\
\hline $\begin{array}{l}\text { Triacylglycerols }(\mathrm{mg} / \mathrm{g}) \\
\text { Cholesterol }(\mathrm{mg} / \mathrm{g}) \\
\text { Phospholipids (mg/g) }\end{array}$ & $\begin{array}{r}5 \cdot 5^{\mathrm{a}} \\
3 \cdot 1^{\mathrm{a}} \\
13 \cdot 4^{\mathrm{a}}\end{array}$ & $\begin{array}{l}0 \cdot 8 \\
0 \cdot 3 \\
1 \cdot 3\end{array}$ & $\begin{array}{r}12 \cdot 3^{\mathrm{b}} \\
4 \cdot 4^{\mathrm{b}} \\
29 \cdot 6^{\mathrm{b}}\end{array}$ & $\begin{array}{l}1 \cdot 7 \\
0.6 \\
3.7\end{array}$ & $\begin{array}{r}8 \cdot 3^{\mathrm{c}} \\
4 \cdot 7^{\mathrm{b}} \\
32 \cdot 3^{\mathrm{b}}\end{array}$ & $\begin{array}{l}0.9 \\
0.5 \\
3.8\end{array}$ & $\begin{array}{r}1 \cdot 9^{d} \\
6 \cdot 7^{c} \\
26 \cdot 5^{b}\end{array}$ & $\begin{array}{l}0.6 \\
0.6 \\
3 \cdot 2\end{array}$ \\
\hline
\end{tabular}

$\mathrm{OO}$, olive oil; HOSO, high-oleic-acid sunflower oil; FO, fish oil.

a,b,c,d Mean values within a row not sharing a common superscript letter were significantly different: $P<0.05$.

* For details of diets and procedures, see Tables 1-3 and pp. 234-235.

reductase were similar in livers of rats fed on the oilenriched diets, and were higher than that for the control animals (Fig. 2(b)).

\section{Discussion}

The present study was designed to determine whether feeding a PUFA oil (FO) or two MUFA oils, prepared from two different sources (OO and HOSO), affects the liver lipid composition and the antioxidant defence system; the plasma lipid composition was also studied.

Liver lipid triacylglycerol levels were lowest in FO-fed rats (Table 6). This may have been due to inhibition of hepatic triacylglycerol synthesis (Wong et al. 1984; Froyland et al. 1997), and stimulation of hepatic peroxisomal $\beta$-oxidation (Yamazaki et al. 1987) produced by the FO diet. Decreases in lipoprotein lipase (EC 3.1.1.34) and triacylglycerol lipase (EC 3.1.1.3) activities in the liver after FO consumption have also been described (Huff et al. 1993), and this may be an adaptive response to the low concentrations of substrates (triacylglycerols) for these enzymes. The low levels of triacylglycerols in liver after FO consumption may also be related to the reduced levels of plasma triacylglycerols found in our study (Table 5) and also described by others in man (Phillipson et al. 1985) and rats (Yamazaki et al. 1987).

The $\mathrm{OO}$ diet resulted in a higher liver triacylglycerol content than the HOSO diet. This fact has been recently corroborated by other studies from our group (Perona \& Ruiz-Gutierrez, 1998), in which it has been reported that the

Table 7. Fatty acid composition ( $\mathrm{g} / 100 \mathrm{~g}$ total fatty acids) of the liver lipids of rats fed for 12 weeks on diets containing different fats*

(Mean values with their standard errors for ten rats per group)

\begin{tabular}{|c|c|c|c|c|c|c|c|c|}
\hline \multirow{2}{*}{$\begin{array}{l}\text { Diet ... } \\
\text { Fatty acid }\end{array}$} & \multicolumn{2}{|c|}{ Control } & \multicolumn{2}{|c|}{ OO } & \multicolumn{2}{|c|}{ HOSO } & \multicolumn{2}{|c|}{ FO } \\
\hline & Mean & SE & Mean & SE & Mean & SE & Mean & SE \\
\hline $14: 0$ & 0.4 & 0.1 & 0.3 & 0.1 & 0.4 & 0.1 & 0.4 & $0 \cdot 1$ \\
\hline $16: 0$ & $21 \cdot 1^{\mathrm{a}}$ & 0.4 & $15 \cdot 4^{b}$ & $2 \cdot 0$ & $17 \cdot 3^{b}$ & 0.7 & $22 \cdot 3^{\mathrm{a}}$ & 1.0 \\
\hline $16: 1 n-7$ & 1.8 & 0.3 & $1 \cdot 1$ & 0.1 & 1.5 & 0.1 & $1 \cdot 1$ & $0 \cdot 1$ \\
\hline $18: 0$ & $18 \cdot 5^{\mathrm{a}}$ & 3.3 & $13 \cdot 9^{b}$ & 0.7 & $13 \cdot 3^{b}$ & $2 \cdot 1$ & $19 \cdot 7^{a}$ & 1.8 \\
\hline $18: 1 n-9$ & $13 \cdot 1^{a}$ & 1.3 & $27 \cdot 7^{\mathrm{b}}$ & 0.5 & $24 \cdot 6^{b}$ & $2 \cdot 7$ & $8 \cdot 4^{c}$ & 0.2 \\
\hline $18: 1 n-7$ & 1.4 & 0.1 & 1.5 & 0.4 & 1.7 & 0.1 & 1.0 & $0 \cdot 1$ \\
\hline $18: 2 n-6$ & $13 \cdot 1$ & 1.7 & 11.9 & 0.5 & $13 \cdot 3$ & 1.1 & 13.9 & 1.6 \\
\hline $18: 3 n-3$ & $0.3^{\mathrm{a}}$ & 0.0 & $0.2^{b}$ & 0.0 & $0.2^{b}$ & 0.0 & $0.3^{\mathrm{a}}$ & 0.0 \\
\hline $20: 0$ & $0.5^{\mathrm{a}}$ & 0.1 & $0.2^{b}$ & 0.1 & $0.3^{\mathrm{b}}$ & 0.0 & $0.3^{b}$ & 0.0 \\
\hline $20: 1 n-9$ & $0.1^{\mathrm{a}}$ & 0.0 & $0.4^{b}$ & 0.1 & $0.3^{b}$ & 0.0 & $0.1^{\mathrm{a}}$ & 0.0 \\
\hline $20: 4 n-6$ & $23 \cdot 2^{a}$ & 1.6 & $21 \cdot 9^{a}$ & 1.5 & $21 \cdot 6^{\mathrm{a}}$ & 1.6 & $15 \cdot 6^{b}$ & 0.7 \\
\hline $20: 5 n-3$ & $0.2^{a}$ & 0.0 & $0.1^{a}$ & 0.0 & $0.1^{\mathrm{a}}$ & 0.0 & $3.0^{\mathrm{b}}$ & 0.9 \\
\hline $22: 0$ & $0.6^{\mathrm{a}}$ & 0.1 & $0.5^{\mathrm{a}}$ & 0.1 & $0.7^{\mathrm{a}}$ & 0.1 & $0.9^{b}$ & 0.0 \\
\hline $22: 4 n-6$ & $0.5^{\mathrm{a}}$ & 0.0 & $0.4^{\mathrm{a}}$ & 0.1 & $0.3^{a}$ & 0.1 & $0.6^{\mathrm{b}}$ & 0.0 \\
\hline $22: 5 n-6$ & $0.6^{\mathrm{a}}$ & 0.2 & $0.4^{\mathrm{a}}$ & 0.1 & $0.4^{\mathrm{a}}$ & 0.1 & $0.2^{b}$ & 0.0 \\
\hline $22: 5 n-3$ & $0.7^{\mathrm{a}}$ & 0.1 & $0.3^{b}$ & 0.1 & $0.4^{b}$ & 0.1 & $1 \cdot 7^{\mathrm{c}}$ & 0.4 \\
\hline $22: 6 n-3$ & $3.8^{a}$ & 0.6 & $3.6^{a}$ & 0.8 & $3 \cdot 3^{a}$ & 0.4 & $11 \cdot 1^{c}$ & 1.8 \\
\hline SFA & $41 \cdot 1^{\mathrm{a}}$ & 3.4 & $30 \cdot 3^{b}$ & 2.8 & $31.9^{b}$ & 2.9 & $43 \cdot 5^{\mathrm{a}}$ & $2 \cdot 8$ \\
\hline MUFA & $16 \cdot 5^{\mathrm{a}}$ & 1.7 & $30 \cdot 8^{b}$ & $1 \cdot 1$ & $28 \cdot 1^{b}$ & $2 \cdot 4$ & $10 \cdot 6^{c}$ & 0.5 \\
\hline PUFA & $42 \cdot 4^{\mathrm{a}}$ & 3.4 & $39.0^{\mathrm{b}}$ & $2 \cdot 3$ & $39 \cdot 7^{b}$ & 1.3 & $45 \cdot 9^{a}$ & 1.7 \\
\hline Total $n-6$ & $37.4^{a}$ & 3.9 & $34 \cdot 7^{\mathrm{a}}$ & 2.2 & $35 \cdot 7^{a}$ & 3.7 & $29.9^{b}$ & $2 \cdot 2$ \\
\hline Total $n-3$ & $5 \cdot 0^{a}$ & 0.4 & $4 \cdot 3^{a}$ & 0.4 & $4 \cdot 0^{\mathrm{a}}$ & 0.4 & $16 \cdot 1^{\mathrm{b}}$ & 2.9 \\
\hline$n-6: n-3$ & $7 \cdot 5^{\mathrm{a}}$ & 1.9 & $8 \cdot 1^{\mathrm{a}}$ & $1 \cdot 7$ & $8.9^{a}$ & 2.3 & $1.9^{b}$ & 0.6 \\
\hline MUFA :SFA & $0.4^{\mathrm{a}}$ & 0.3 & $1.0^{b}$ & 0.3 & $0.9^{b}$ & 0.2 & $0.2^{a}$ & $0 \cdot 1$ \\
\hline $20: 4 / 18: 2$ & $1 \cdot 7^{\mathrm{a}}$ & 0.4 & $1.8^{\mathrm{a}}$ & 0.5 & $1.6^{\mathrm{a}}$ & 0.3 & $1 \cdot 1^{\mathrm{b}}$ & 0.2 \\
\hline
\end{tabular}

OO, olive oil; HOSO, high-oleic-acid sunflower oil; FO, fish oil; SFA, saturated fatty acids; MUFA, monounsaturated fatty acids; PUFA, polyunsaturated fatty acids.

${ }^{a, b, c}$ Mean values within a row not sharing a common superscript letter were significantly different: $P<0.05$.

${ }^{*}$ For details of diets and procedures, see Tables 1-3 and pp. 234-235. 


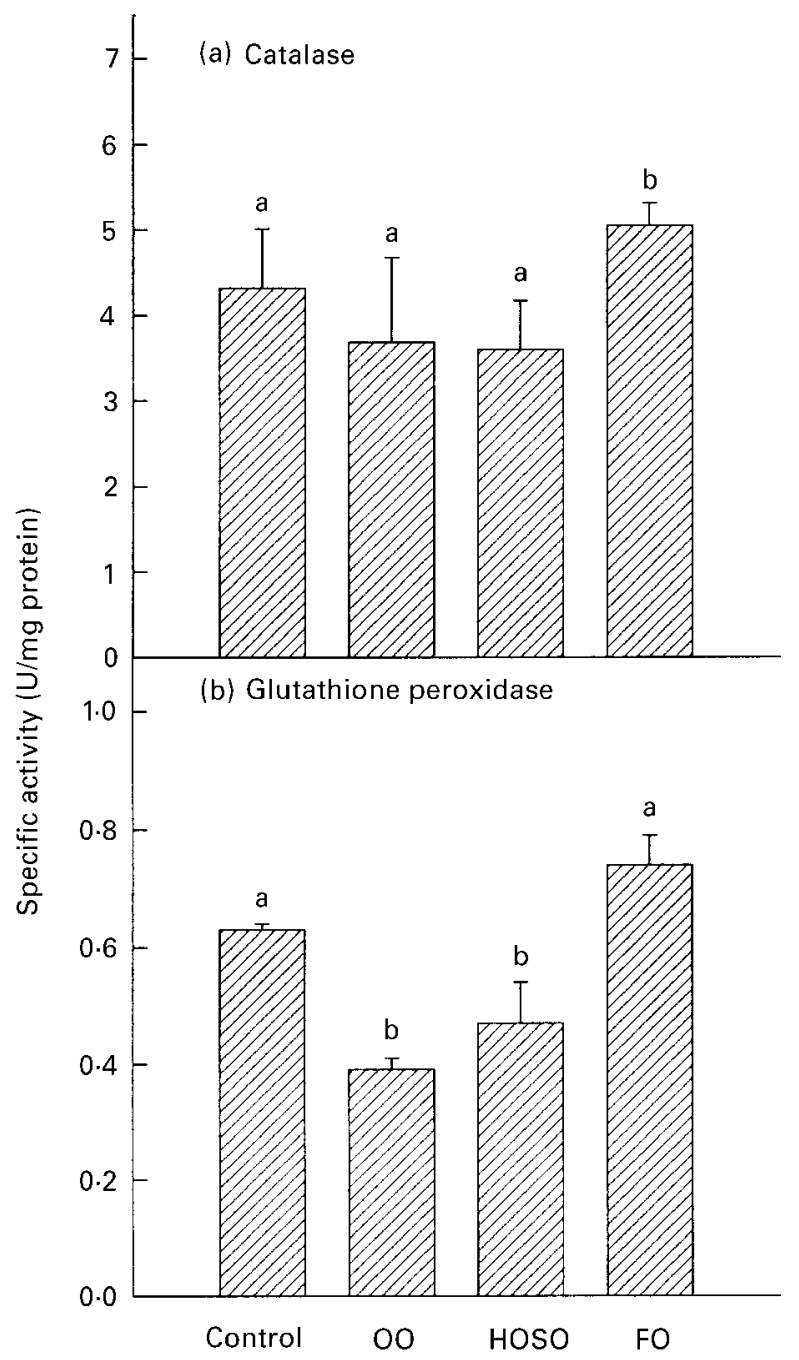

Fig. 1. Specific activities of (a) catalase and (b) glutathione peroxidase in the livers of rats fed for 12 weeks on a control diet or diets containing $100 \mathrm{~g} / \mathrm{kg}$ of olive oil (OO), high-oleic-acid sunflower oil (HOSO) or fish oil (FO). Values are means for ten rats per group, with standard deviations represented by vertical bars. ${ }^{a, b}$ Mean values not sharing a common letter were significantly different: $P<0.05$.

consumption of $\mathrm{OO}$ results in a greater amount of liver triacylglycerol when compared with consumption of HOSO. These results suggest that factors other than the oleic acid content of the oils may be responsible for enhancing triacylglycerol synthesis in the liver of the animals fed on the OO diet. Furthermore, the same authors in the present study observed different distributions of triacylglycerol molecular species in rat liver; OO led to a higher content of dioleoacylglycerol species while the HOSO diet led to an increase in saturated triacylglycerol species, suggesting that these effects may be due to an enhancement in the synthesis of such molecular species. In plasma we did not observe differences in triacylglycerol content for the two high-oleic-acid diets studied.

Cholesterol levels in liver were increased in animals fed on the lipid-supplemented diets compared with the control group (Table 6). The FO diet led to higher values than the $\mathrm{HOSO}$ and $\mathrm{OO}$ diets. The increased liver cholesterol content

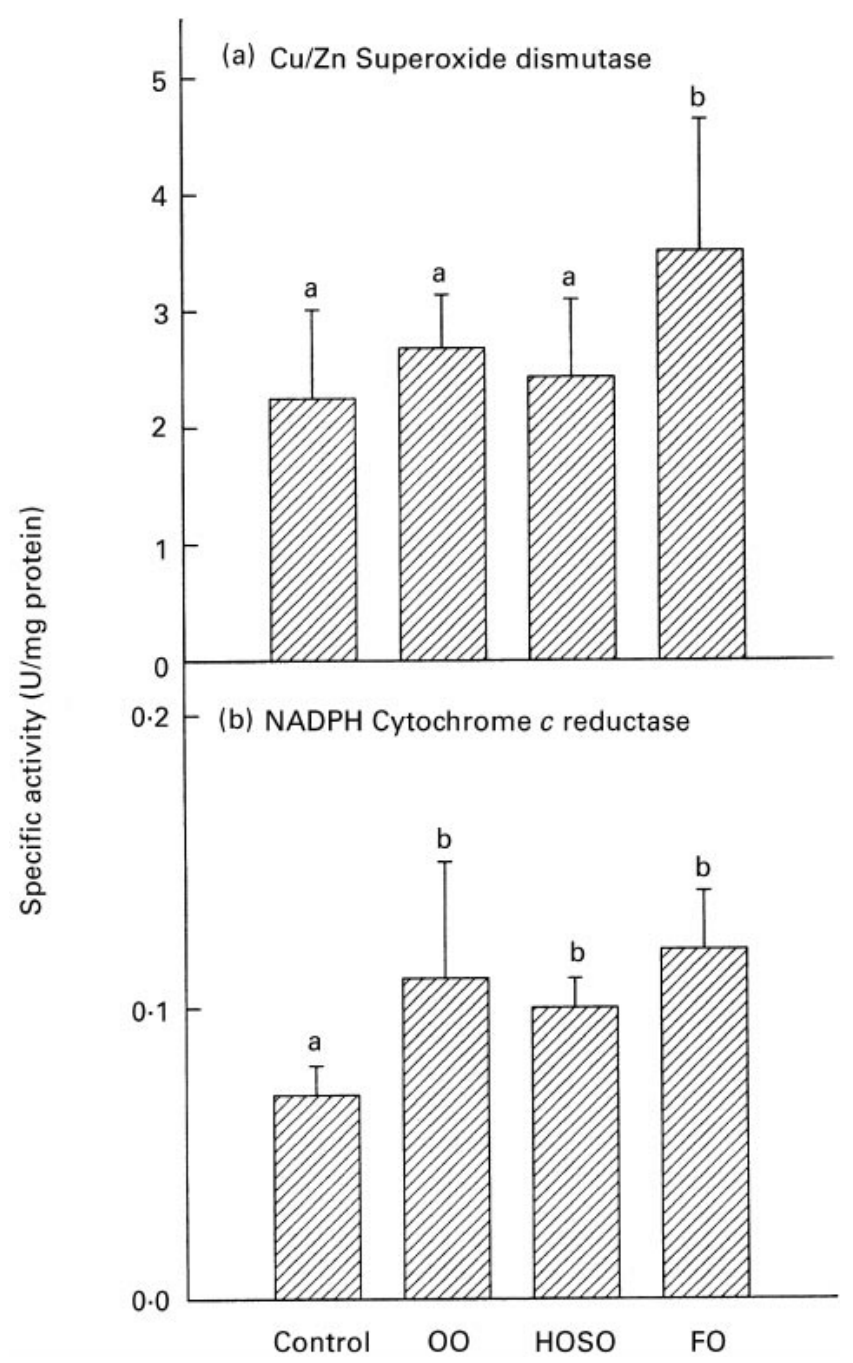

Fig. 2. Specific activities of (a) Cu/Zn superoxide dismutase and (b) NADPH-cytochrome $c$ reductase in the livers of rats fed for 12 weeks on a control diet or diets containing $100 \mathrm{~g} / \mathrm{kg}$ of olive oil (OO), higholeic-acid sunflower oil (HOSO) or fish oil (FO). Values are means for ten rats per group, with standard deviations represented by vertical bars. ${ }^{a, b}$ Mean values not sharing a common letter were significantly different: $P<0.05$.

in the FO-fed rats might have been due to the increased squalene content in this diet compared with the others (Table 3). The dietary effect of this precursor of cholesterol biosynthesis is not clear, but it has been shown to increase biliary cholesterol secretion (Ulloa \& Nervi, 1985). In plasma we found a lower cholesterol level in the FO group than in the $\mathrm{OO}$ and HOSO groups. It has also been described that FO consumption reduces cholesterol levels in blood, and that it is more hypocholesterolaemic than $\mathrm{OO}$ (Masi et al. 1986). Garg et al. (1988) reported that PUFA lower cholesterol levels in man and animals due to a redistribution of cholesterol from blood to tissues.

We found high cholesterol levels in both liver and plasma following oleic acid feeding compared with the control diet. This hypercholesterolaemic effect of a diet high in $\mathrm{OO}$ in serum and liver of rats has been reported previously by Yaqoob et al. (1995). Jeffery et al. (1996) confirmed the 
effect on serum total cholesterol concentrations in rats fed on diets containing OO or HOSO. In man, however, hypocholesterolaemic effect of MUFA is well established (Mattson \& Grundy, 1985) although the mechanism by which it is brought about remains unclear.

Analysis of the fatty acid composition in rat liver homogenates showed a significant increase of 18:1 in liver lipids obtained from OO- and HOSO-fed rats. We also found lower saturated fatty acid levels in both groups. This increase in oleic acid content was probably related to the higher content of oleic acid in the diet of these animals. It has been reported that when endothelial cell cultures are directly supplemented with oleic acid, an increase in its content is found, accompanied by a decrease in the saturated acid content (Spector \& Yorek, 1985).

With respect to the FO diet, we found a marked increase in the proportion of total $n-3$ fatty acids (mainly 20:5 and 22:6), and a concomitant decrease in $n-6(20: 4,22: 4$ and 22:5) fatty acids in the liver. As a consequence, a significant reduction in the ratio $n-6: n-3$ was found in these animals. Other authors have reported a decrease in arachidonic acid in liver (Venkatraman et al. 1994) and lung (Archer et al. 1987 ) in animals fed on FO.

Animals fed on the FO diet had higher activities of GSHPx, CAT and $\mathrm{Cu} / \mathrm{Zn}$ SOD compared with those fed on the control diet and the oleic-acid-enriched diets. Because the lipid composition of the liver of rats reflected the lipid composition of the diet, the liver lipids of the rats fed on the FO diet contained higher levels of PUFA. This fact might render the livers of rats fed on the FO diet more susceptible to lipid peroxidation and the activity of antioxidant enzymes might be induced. A potential mechanism for the induction of hepatic antioxidants following FO feeding might be an increase of the expression of their genes; induction of the expression of antioxidant enzymes has been reported in circumstances where an increase in free radicals is produced, such as ageing (De Haan et al. 1992) or several pathologies (Ceriello et al. 1996; Larrea et al. 1998). It is also well known that free radicals may regulate the transcription of many other genes (Cramer et al. 1995; Roche \& Romero-Alvira, 1995).

This greater activity of antioxidant enzymes may contribute to the hypothesis that consumption of FO extends lifespan. This fact has been described in animal models of autoimmune disease (Jeng \& Fernandes, 1989). Antioxidants have been closely linked with the preservation of health and longevity in both mice and rats (Semsei et al. 1989; Rao et al. 1990).

Yamazaki et al. (1987) found that feeding FO to animals increased the activities of some liver enzymes (fatty acylCoA synthetase (EC 2.3.1.85), CAT and GSH-Px) when compared with safflower-oil-fed animals. Venkatraman et al. (1994) described an increase in the activities and mRNA expression of CAT, GSH-Px and SOD in mice fed on a diet rich in FO compared with other diets rich in n-6 lipids. Recently, the same group has reported increases in CAT and GSH-Px activities in sedentary and exercised Fischer-344 rats respectively, after consumption of FO, and non-significant changes in membrane lipid peroxidation (Venkatraman et al. 1998). In contrast, L'Abbe et al. (1991) reported that diets high in $n-3$ fatty acids elevate the lipid peroxidation in heart and liver, due in part to decreased SOD and GSH-Px activities. Nalbone et al. (1980) reported that the GSH-Px activity of rats fed on FO diets remained unchanged in liver. Berge \& Thomassen (1985) showed that CAT activity was affected only slightly by a FO diet, and Van Noorden (1995) described a moderate increase in CAT activity.

Less attention has been paid to the effect of oleic-acidenriched diets on antioxidant enzymes. In our studies we have not found differences in the activities of the antioxidant enzymes between the two high-oleic-acid diets tested. The non-glyceride fractions of these oils are different (Table 3 ); polyphenols, which have free-radical-scavenging properties, are only present in $\mathrm{OO}$, and tocopherols, which also have an antioxidant effect, are higher in OO. These differences in the natural antioxidant content in the two oils seems not to affect the activity of the hepatic antioxidant enzymes studied.

NADPH-cytochrome $c$ reductase participates in the detoxification of drugs and xenobiotics. Similar activities of NADPH-cytochrome $c$ reductase were observed in rats fed on the OO, HOSO and FO diets in the present study, and each oil diet supported higher activity than the control diet. Hepatic NADPH-cytochrome $c$ reductase activity was not significantly affected by the FO diet in comparison with a low-fat diet or diets enriched in $n-6$ PUFA (Van Noorden, 1995). The concentration of cytochrome P450 and rates of oxidative drug metabolism were greater when polyunsaturated fats were incorporated into the diet than when fat-free diets or saturated fats were given (Smith \& Willis, 1981).

In summary, it appears that changes in the liver fatty acid composition, due mainly to $n$ - 3 lipids, may increase the activity of some antioxidant enzymes, compensating the risk of carcinogenesis due to the peroxidation of PUFA and free-radical production. On the other hand, the two MUFA oils studied (OO and HOSO), in spite of their different contents of natural antioxidants, have similar effects on the antioxidant enzyme activities studied.

\section{Acknowledgements}

This study was supported by Grant ALI96-0456 from the Comision Interministerial de Ciencia y Tecnología, Spain. We wish to thank Koipe S.A. and Aceites Toledo. We are grateful to Fernanda León and Manuel Rodriguez-Aguilar for expert technical assistance.

\section{References}

Allain CC, Poon LS, Chang CSG, Richmond W \& Fu PC (1974) Enzymatic determination of total plasma cholesterol. Clinical Chemistry 20, 470-475.

Arce L, Rios A \& Valcarcel M (1998) Determination of anticarcinogenic polyphenols present in green tea using capillary electrophoresis coupled to a flow injection system. Journal of Chromatography A 827, 113-120.

Archer S, Nelson D, Gebhard R, Levine AS, Prigge W \& Weir EK (1987) Effects of dietary fish oil on lung phospholipid fatty acid composition and intrinsic pulmonary vascular reactivity. Cardiovascular Research 21, 928-932.

Bang HO, Dyerberg J \& Nielsen AB (1986) Plasma lipid and lipoprotein pattern in Groenlandic West-coast Eskimos. Nutrition Reviews 44, 143-146. 
Beers RF \& Sizer IW (1952) A spectrophotometric method for measuring the breakdown of hydrogen peroxide by catalase. Journal of Biological Chemistry 195, 133-140.

Berge RK \& Thomassen MS (1985) Effects of high-fat diets on the activity of palmitoyl-CoA hydrolase in rat liver. Lipids 20, 49-52.

Bucolo G \& David H (1973) Quantitative determination of plasma triglycerides by use of enzymes. Clinical Chemistry 19, 476482.

Ceriello A, dello Russo P, Amstad P \& Cerutti P (1996) High glucose induces antioxidant enzymes in human endothelial cells in culture. Evidence linking hyperglycemia and oxidative stress. Diabetics 45, 471-477.

Cramer CT, Cooke S, Ginsberg LC, Kletzien RF, Stapleton SR \& Ulrich RG (1995) Upregulation of glucose-6-phosphate dehydrogenase in response to hepatocellular oxidative stress: studies with diquat. Journal of Biochemical Toxicology 10, 293-298.

De Haan JB, Newman JD \& Kola I (1992) Cu/Zn superoxide dismutase mRNA and enzyme activity, and susceptibility to lipid peroxidation, increases with ageing in murine brains. Brain Research-Molecular Brain Research 13, 179-187.

De Schrijver R \& Vermeulen D (1991) Separation and quantification of phospholipids in animal tissues by Iatroscan TLC/FID. Lipids 26, 74-75.

Fang JL, Vaca CE, Valsta LM \& Mutanen M (1996) Determination of DNA adducts of malonaldehyde in humans: effects of dietary fatty acid composition. Carcinogenesis 17, 1035-1040.

Folch J, Lees M \& Sloane-Stanley GH (1957) A simple method for the isolation and purification of total lipides from animal tissues. Journal of Biological Chemistry 226, 497-509.

Froyland L, Madsen L, Vaagenes H, Totland GK, Auwerx J, Kryvi H, Staels B \& Berge RK (1997) Mitochondrion is the principal target for nutritional and pharmacological control of triglyceride metabolism. Journal of Lipid Research 38, 1851-1858.

Garcia Regueiro JA, Gilbert J \& Diaz I (1994) Determination of neutral lipids from subcutaneous fat of cured ham by capillary gas chromatography and liquid chromatography. Journal of Chromatography A 667, 225-233.

Garg ML, Sebokova E, Wierzbicki A, Thomson AB, Thomson R \& Clandinin MT (1988) Differential effects of dietary linoleic and $\alpha$-linolenic acid on lipid metabolism in rat tissues. Lipids $\mathbf{2 3}$, 847-852.

Harman D (1992) Free radical theory of ageing. Mutation Research 275, 257-266.

Herold PM \& Kinsella JE (1986) Fish oil consumption and decreased risk of cardiovascular disease: a comparison of findings from animal and human feeding trials. American Journal of Clinical Nutrition 43, 566-598.

Huang CY, Chen LH, Osio Y \& Cohen DA (1994) Effects of diet composition on liver antioxidant defence and detoxification enzymes in mice with murine AIDS. Nutrition Research 14, $1841-1851$.

Huff MW, Telford DE, Edmonds BW, McDonalds CG \& Evans AJ (1993) Lipoprotein lipases, lipoprotein density gradient profile and LDL receptor activity in miniature pigs fed fish oil and corn oil. Biochimica et Biophysica Acta 1210, 113-122.

Jeffery NM, Yaqoob P, Newsholme EA \& Calder PC (1996) The effects of olive oil upon rat serum lipid levels and lymphocyte functions appear to be due to oleic acid. Annals of Nutrition and Metabolism 40, 71-80.

Jeng KC \& Fernandes G (1989) Effect of fish oil diet on immune response and proteinuria in mice. International Journal of Immunopathology and Immunopharmacology 126, 1999-2006.

Kok TM, Vaarwerk F, Zwingman I, Maanen JM \& Kleinjans JC (1994) Peroxidation of linoleic, arachidonic and oleic acid in relation to the induction of oxidative DNA damage and cytogenetic effects. Carcinogenesis 15, 1399-1404.

Kramer JK, Blais L, Fouchard RC, Melnyk RA \& Kallery KM
(1997) A rapid method for the determination of vitamin $\mathrm{E}$ forms in tissues and diet by high-performance liquid chromatography using a normal-phase diol column. Lipids 32, 323-330.

Kromhout D, Bosschieter EB \& Coulander CL (1985) The inverse relation between fish consumption and 20-year mortality from coronary heart disease. New England Journal of Medicine 312, 1205-1209.

L'Abbe MR, Trick KD \& Beare-Rogers JL (1991) Dietary (n-3) fatty acids affect rat heart, liver and aorta protective enzyme activities and lipid peroxidation. Journal of Nutrition 121, 1331-1340.

Larrea E, Beloqui O, Muñoz-Navas MA, Civeira MP \& Prieto J (1998) Superoxide dismutase in patients with chronic hepatitis C virus infection. Free Radical Biology and Medicine 24, 12351241.

Lawrence A \& Burk RF (1976) Glutathione peroxidase activity in selenium deficient rat liver. Biochemical and Biophysical Research Communications 71, 952-958.

Lowry OH, Rosebrough NJ, Farr AL \& Randall RL (1951) Protein measurement with the Folin phenol reagent. Journal of Biological Chemistry 193, 265-275.

McCord JM \& Fridovich I (1969) Superoxide dismutase. An enzymatic function for erythrocuprein (hemocuprein). Journal of Biological Chemistry 244, 6049-6055.

Masi I, Giani E, Galli C, Tremoli E \& Sirtori CR (1986) Diets rich in saturated, monounsaturated and polyunsaturated fatty acids differently affect plasma lipid, platelet and arterial wall eicosanoids in rabbits. Annals of Nutrition and Metabolism 30, 66-72.

Mattson FH \& Grundy SM (1985) Comparison of effects of dietary saturated, monounsaturated and polyunsaturated fatty acids on plasma lipids and lipoproteins in man. Journal of Lipid Research 26, 194-202.

Molina MT, Vázquez CM \& Ruiz-Gutiérrez V (1989) Changes in both acyl-CoA:cholesterol acyltransferase activity and microsomal lipid composition in rat liver induced by distal smallbowel resection. Biochemical Journal 260, 115-119.

Nalbone G, Leonardi J, Termine E, Portugal H, Lechene P, Pauli A \& Lafont H (1980) Effects of fish oil, corn oil and lard diets on lipid peroxidation status and glutathione peroxidase activities in rat heart. Lipids 24, 179-186.

Nelson GJ (1972) Quantitative analysis of bloods lipids. In Blood Lipids and Lipoproteins: Quantitation, Composition and Metabolism, pp. 171-198 [GJ Nelson, editor]. New York, NY: Wiley-Interscience.

Papadopoulos G \& Boskou D (1991) Antioxidant effect of natural phenols in olive. Journal of the American Oil Chemists' Society 68, 669-671.

Pérez-Jiménez F, Espino A, López-Segura F, Blanco J, RuizGutiérrez V, Prada JL, López Miranda J, Jiménez-Perezpérez J \& Ordovas JM (1995) Lipoprotein concentrations in normolipidemic males consuming oleic acid-rich diets from two different sources: olive oil and oleic-acid-rich sunflower oil. American Journal of Clinical Nutrition 62, 769-775.

Perona JS \& Ruiz-Gutierrez V (1998) Two highly monounsaturated oils, olive oil and high-oleic sunflower oil, induce different triacylglycerol molecular species distribution in rat liver. Nutrition Research 18, 1723-1732.

Phillipson BE, Rothrock DW, Connor WE, Harris WS \& Illingworth DR (1985) Reduction of plasma lipids, lipoproteins and apoproteins by dietary fish oils in patients with hypertriglyceridemia. New England Journal of Medicine 312, 1210-1216.

Rao G, Xia E \& Richardson A (1990) Effect of age on the expression of antioxidant enzymes in male Fischer F 344 rats. Mechanisms in Ageing Development 53, 49-60.

Roche E \& Romero-Alvira D (1995) Role of oxidative stress in gene expression: myocardial and cerebral ischemia, cancer and other diseases. Medicina Clinica 104, 468-476.

Semsei I, Rao G \& Richardson A (1989) Changes in the expression 
of superoxide dismutase and catalase as a function of age and dietary restriction. Biochemical and Biophysical Research Communications 164, 620-625.

Smith MT \& Willis ED (1981) The effects of dietary lipid and phenobarbitone on the production and utilization of NADPH in the liver. Biochemical Journal 200, 691-699.

Spector AA \& Yorek MA (1985) Membrane lipid composition and cellular function. Journal of Lipid Research 26, 1015-1035.

Sulpice JC \& Ferezou J (1984) Squalene isolation by HPLC and quantitative comparison by HPLC and GLC. Lipids 19, 631-635.

Ulloa N \& Nervi F (1985) Mechanism and kinetic characteristics of the uncoupling by plant steroids of biliary cholesterol from bile salt output. Biochimica et Biophysica Acta 837, 181-189.

Van Noorden CJF (1995) Effects of $n-3$ and $n-6$ polyunsaturated fatty acid-enriched diets on lipid metabolism in periportal and pericentral compartments of female rat liver lobules and the consequences for cell proliferation after partial hepatectomy. Journal of Lipid Research 36, 1708-1720.

Venkatraman JL, Angkeow P, Satsangi N \& Fernandes G (1998) Effects of dietary $n-6$ and $n-3$ lipids on antioxidant defence system in livers of exercised rats. Journal of the American College of Nutrition 17, 586-594.
Venkatraman JT, Chandrasekar B, Kim JD \& Fernandes G (1994) Effects of $n-3$ and $n-6$ fatty acids on the activities and expression of hepatic antioxidant enzymes in autoimmune-prone NZB $\times$ NZW $F_{1}$ mice. Lipids 29, 561-568.

Vermilion JL \& Coon MJ (1978) Purified liver microsomal NADPH-cytochrome P450 reductase. Spectral characterization of oxidation-reduction states. Journal of Biological Chemistry 253, 2694-2704.

Wong SH, Nestel PJ, Trimble RP, Store GB, Illman RJ \& Topping DL (1984) The adaptive effects of dietary fish and safflower oil on lipid and lipoprotein metabolism in perfused rat liver. Biochimica et Biophysica Acta 792, 103-109.

Yamazaki RK, Shen T \& Schade GB (1987) A diet rich in (n-3) fatty acids increases peroxisomal $\beta$-oxidation activity and lowers plasma triacylglycerols without inhibiting glutathionedependent detoxification activities in the rat liver. Biochimica et Biophysica Acta 920, 62-67.

Yaqoob P, Sherrington EJ, Jeffery NM, Sanderson P, Harvey DJ, Newsholme EA \& Calder PC (1995) Comparison of the effects of a range of dietary lipids upon serum and tissue lipid composition in the rat. International Journal of Biochemistry 27, 297-310. 